\title{
The gendered impact of pandemics on poor women: The case of COVID-19 in South Africa
}

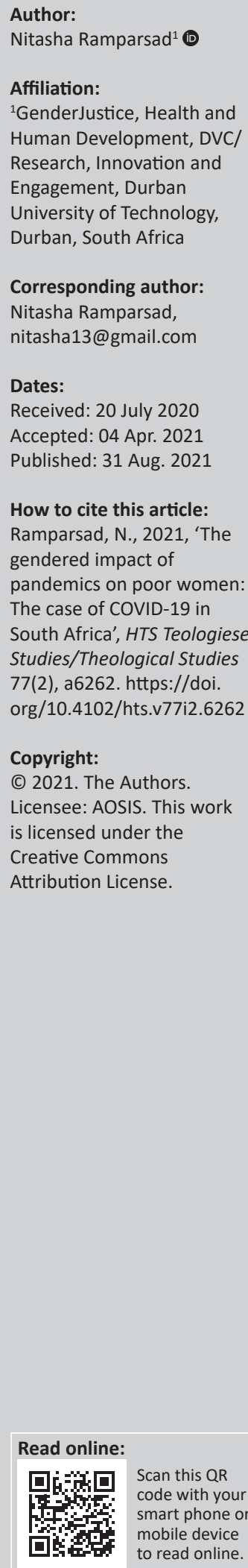

This article provides a reflection on the coronavirus disease 2019 (COVID-19) pandemic and its effect on poor women in South Africa. The article provides a unique insight into the gendered impact of COVID-19, specifically assessing women in informal settlements and townships. The article interrogates poor women who are unable to implement the suggested measures to reduce the spread of the virus. The focus is on poor women as this group was considered most vulnerable, notably because of the dependency on the salaries of poor women. The article enlists how this pandemic is different from others in the sense that there is a differentiated impact on poor women. The differentiated impact is discussed under various themes, including ability to social distance, transportation implications, access to food and access to the COVID-19 relief grant. Access to COVID-19 grants and subsequent relief measures are assessed for their accessibility to poor women. The discussion engages the latest statistics available in 2020 during the pandemic and also reflects on what this means for the future. The article broadly explores the poverty gap and how this impacts poor women and looks at inequality in terms of labour demands on poor women during the pandemic. Finally, the article suggests some reforms that could be implemented going forward for poor women by government and other stakeholders, given that many cannot access their employment in a safe manner, and also looks at social reforms in terms of access to relief efforts for poor communities.

Contribution: This article focuses on the most marginalised group of people in South African society affected by COVID-19, namely, poor women. The article provides a unique contribution by assessing the consequences of the pandemic and looks at possible recommendations for addressing the plight of poor women in South Africa post-COVID-19.

Keywords: poor; women; COVID-19; economic impact; South Africa.

\section{Introduction}

On 23 March, President Cyril Ramaphosa addressed the nation and announced a 21-day national lockdown effective from midnight of 27 March to 16 April, with the deployment of the South African National Defence Force (SADF) to support the government. All activities were suspended except for essential services (Business Tech 2020a).

With the arrival of the pandemic, there was a distinct positioning of poor women who remained at higher risk than others. Many poor black women live in rural, peri-urban and informal settlements. Social distancing was enforced as a major prevention mechanism. This is impossible for certain sectors of the population; for example, black women living in an informal settlement in Khayelitsha who use a communal toilet and communal tap with no access to warm water or electricity cannot maintain social distance and keep up the hygiene standards expected during the pandemic (Blouws 2020).

Firstly, many did not understand how the virus could possibly spread; secondly, living in lockdown was not feasible for many, with a significant number of people leaving their dwellings in search of food; and thirdly, most believed that the coronavirus disease 2019 (COVID-19) was not any more hazardous than their daily realities. 'If anything, the lockdown feels unnecessarily oppressive (to them)', the researchers noted. Based on these findings, it is clear that social distancing, a major measure put in place for the containment of the virus, was indeed unachievable in townships.

\section{Inequality in South Africa}

Unpaid work undoubtedly continues during the pandemic and therefore places an additional burden on women who would otherwise put less effort in terms of time allocation for labour. The

Note: Special Collection: Gender Justice, Health and Human Development, sub-edited by Cheryl Potgieter (Durban University of Technology). 
labour burden on poor women is significantly more (see Roncolato \& Radchenko 2016). It is important to recognise the role that patriarchy and discrimination play in how women are viewed, their contribution to the household, the economic value that their work holds and all the stereotypes that are present within our communities. We also need to recognise intersectionality and privilege, as women are not homogeneous and in a country such as South Africa, women experience discrimination in very different ways (May \& Hamdulay 2019).

\section{Poverty gap for women in South Africa}

The Living Conditions Survey (LCS) is part of Statistics South Africa's (Stats SA) household survey programme and provides detailed information on households' living circumstances and their income and expenditure patterns. Information from this survey was used to compile the report 'Men, Women and Children: Findings of the LCS (2014/2015)'.

The poverty gap (the distance away from the poverty line) and severity of poverty measures were larger for femaleheaded households compared with male-headed households. The proportion of women living below the Upper Bound Poverty Line (UBPL) was 16.9 percentage points more than that of households headed by men (49.9\% vs. 33.0\%). Almost 6 out of every 10 households headed by men (59.3\%) compared with over 7 out of every 10 households headed by women $(74.8 \%)$ in traditional areas were living under the UBPL.

About $91.4 \%$ of poor male-headed households were connected to electricity compared with $95.2 \%$ of poor femaleheaded households. For poor female-headed households, $69.6 \%$ had full access to water compared with $71.7 \%$ of poor male-headed households.

Notably the largest contributor to overall income inequality came from the labour market, $74 \%$ according to the survey (Stats SA 2015). Female workers earn approximately 30\%

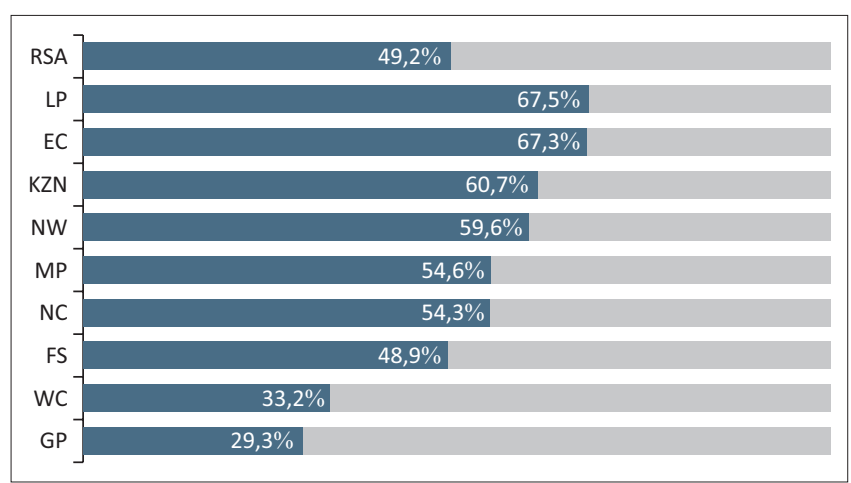

Source: Statistics South Africa, 2014/2015, Findings of the Living Conditions Survey (LCS) 2014/15, viewed 10 June 2020, from http://www.statssa.gov.za/wp-content/ uploads/2019/04/data1.jpg.

RSA, Republic of South Africa; LP, Limpopo province; EC, Eastern Cape; KZN, KwaZulu-Natal; NW, North West; MP, Mpumalanga; NC, Northern Cape; FS, Free State; WC, Western Cape GP, Gauteng province.

FIGURE 1: Labour market survey. less, on average, than male workers. The report reveals that men are more likely to be employed and have relatively better-paying jobs compared with women.

The differences in annual mean and median expenditures by province show the reality of interprovincial inequality. Gauteng and Western Cape were better off when compared with other provinces (Figure 1). Since 2006, there has been a greater dependence on social grants and less reliance on income from the labour market in the bottom deciles. This is evident amongst poor black women who are hardest hit by the pandemic. In contrast, there was greater reliance on income from the labour market in the top deciles.

It has long been understood that in South Africa, if you are able-bodied and of working age but unemployed, there are no social security transfers for you outside of the child support grant, the value of which will be R445 per month per child as of April 2020. This vulnerable group is dependent on extended networks of people who have jobs and people who draw social grants, self-employment as observed by Elsey (2020). The Southern Africa Social Policy Research Institute estimates that if everyone who is not receiving a benefit were to be given R561 per month for three months (R561 is the food poverty line, in 2019 rands), then this would cost about R18.6 billion per month. This measure should have been considered as additional measures during the pandemic because of the loss of income for poor workers. Even so, bringing new people onto a register is a challenging prospect at the best of times. When the population is under lockdown to slow the spread of a virus, the task is absurdly difficult as explained by Elsey (2020).

Most domestic workers travel long distances to reach their place of employment and further expose themselves to the risk of infection as the public transport has deteriorated in its condition and in relation to safety. Domestic workers work in private homes, with lack of proper accountability and regulation within the private space. Employers are likely to have domestic workers stay home during this time without consideration of the necessary compensation. This will leave a large group of women and their families entirely destitute and dependent. Blouws (2020) also commented on the realities of black female farmworkers during the pandemic. Farmworkers and farmdwellers are another vulnerable group in society. They live in unhygienic conditions on farms without access to water and electricity. These are people far removed from supervision and working on private land with few resources. These persons live with weakened immune systems and pre-existing conditions because of their working environment where they are not provided with the necessary protective gear and work in far areas without ablution facilities. Visser and Ferrer (2015) discussed this at length in their assessment of the living conditions of farm workers in South Africa; these conditions make women who live and work on farms more susceptible to falling seriously ill should they contract COVID-19. These women live in close proximity and are physically unable to selfisolate from their children and families. 
The reality of social distancing is also true for small living spaces that cannot be regulated. Blouws (2020) reflected on the Cape Flats in the Western Cape and the inability of the residents to implement social distancing.

The spatial make up of the Western Cape is true for other provinces that still see the affects of apartheid in the spatial realities of communities.

\section{Why is this recession different to others?}

Compared with 'regular' recessions, which affect men's employment more severely than women's employment, the employment drop related to social distancing measures has a large impact on sectors with high female employment shares. In addition, closure of schools and day care centres has massively increased childcare needs, which has a particularly large impact on working mothers (see Overseas Development Institute 2016). The effects of the crisis on poor working mothers are likely to be persistent (Alon et al. 2020). This observation is true for South Africa as we see many women in the informal labour market affected by the institution of lockdown. As stated earlier, many poor women work as domestic help and therefore could not access their employment because of the implementation of restrictions on movement.

Workers who lose jobs now forgo returns to experience and are likely to have less secure employment in the future (Jarosch 2014). The consequences are not only limited to those who lose jobs but also to those who were about to enter the labour market for the first time (Altonji, Kahn \& Speer 2016). Many businesses are now becoming much more aware of the childcare needs of their employees and respond by rapidly adopting more flexible work schedules and telecommuting options. Through learning by doing and changing norms, some of these changes are likely to prove persistent. As a result, in many places mothers and fathers alike will gain flexibility in meeting the combined demands of having a career and running a family. As currently women are more exposed to these competing demands, they stand to benefit disproportionately (Alon et al. 2020).

Notably poor women, because of their participation in the informal sector do not benefit from this flexibility. Many women are forced to rely on the social grant system and the newly introduced special COVID-19 grant (SA Government, March 2020). Applications for the special COVID-19 Social Relief of Distress grant are only electronic. This creates a barrier for women who do not have access to the Internet and cannot prioritise money for data to apply for the special grant. Access to the grant was only made possible through applications via WhatsApp, SMS and email. This creates a barrier for poor women who, as stated previously, bear the brunt of the impact of COVID-19 and the subsequent lockdown measures.

The criteria also excluded many single mothers who rely on the child support grant. The grant only applied certain criteria.
Child-headed households were also excluded from the special grant; these are, as indicated earlier according to Stats SA, usually female headed. Additional requirements to access the grant include proof of residence and banking details. Many poor women live in informal settlements or in the proverbial 'back yard' accommodation. Access to proof of residence is not easily available. In addition, banking details are a luxury for poor women. Bank charges eat into already low wages and therefore many do not have formal bank accounts. The website makes room for money transfers but, again, compliance must be met with the documentation required. 'Citizens without bank accounts can also apply. In this case payment will be effected through a money transfer, once all the necessary validations have been completed' (SA Government, March 2020).

Payments for other grants were increased by the South African government to alleviate such exclusion; however, with many poor women being the only breadwinners, the additional access to the COVID-19 grant would have made an impact on the income of their households. These grants could have added value from the beginning of the pandemic and perhaps could have had a greater effect during the hardest lockdown level, level 5.

\section{What else can be done to support poor households?}

The lockdown excludes informal food vendors as essential services. Researchers at the Institute for Poverty, Land and Agrarian Studies (PLAAS) revealed that up to $70 \%$ of households in townships usually source food from informal vendors. The South African government has, as stated earlier, provided relief funds; the R500bn COVID-19 financial support package presented to minimise the pandemic's socio-economic impact and to ensure food security during the lockdown phase illustrates comprehensive disaster management planning. The self-employed are hard hit by the lockdown. Apart from a reference to spaza shops, the early directives shut down all informal trade, even trade in food and basic necessities. Street food traders alone support an estimated 500000 livelihoods nationally and account for $40 \%$ of the informal township economy (Elsey 2020).

It is most unfortunate that, with regard to social services, including the aspect of food security, there has been a major mismatch between policy intent and implementation capacity. The systemic weaknesses residing in those who were assigned the responsibility to disseminate social services have resulted not only in poor control and management of such resources, but, more importantly, in thousands of people not being able to access the well-intended support measures timely, thereby often going hungry (Fourie 2020). Widely reported corruption regarding food parcels erodes the confidence of the poor. Linked to the high poverty rates are that of unemployment. Unemployment stood at 6.7 million at the end of 2019. It is unpleasant to note that unemployment increased by almost $10 \%$ or 587000 individuals over the last 
year. The lockdown is likely to accelerate this trend significantly. In addition to the 6.7 million unemployed, a further 2.86 million people were classified as discouraged work seekers. This refers to those aged from 15 to 65 years who want to work, but have given up looking for work. Under the expanded definition of unemployment, they are also classified as unemployed (Elsey 2020).

The PLAAS (2020) provides some excellent insight into food dynamics for the poor at this time and offers sensible ideas about measures that talk about food security during the national lockdown.

As a result of the non-availability of certain products under the lockdown rules, such as alcohol and cigarettes, gangsterism emerged, especially amongst vulnerable groups (McLaggan 2020). The emergence of gangsterism for products that cannot be attained also creates an unsafe environment for poorer households. The constructive contribution of some gang leaders is not a new phenomenon. In the 1980s, for example, there had been instances when gang leaders agreed to truces to contain retaliatory murders or had prioritised protecting communities and even political activists from the apartheid police. Hence, seeing gangs coming to the fore to fill the gaps left by policy implementation failures is not unexpected.

Domestic violence has increased significantly during COVID-19 and whilst measures have been put in place in terms of relief and safe houses for women, active policing is needed to ensure the safety of women (Tolmay \& Morna 2020). A woman who is experiencing domestic violence from a partner whom she is financially dependent on, whilst carrying out unpaid care work, is reluctant to seek help against her partner because she will be left financially vulnerable once separated.

\section{Conclusion and recommendations}

Structural discrimination that is present in our homes, communities and places of work all contribute to the lack of recognition assigned to women's unpaid care work. Discrimination within the current economic value chain leads to men being paid more than women in the labour market outside of their homes, leaving women dependent on their male counterparts within their family units for their financial well-being, whilst they carry out unpaid care work. Through this dependence, women become vulnerable to poverty. It is clear that black women in South Africa represent the largest group in terms of those experiencing extreme poverty and those most affected by COVID-19 and the impact of the subsequent measures to contain the virus. With the arrival of the pandemic, there was a distinct positioning of poor women that remained at higher risk than others. Many poor black women live in rural, peri-urban and informal settlements. Social distancing was enforced as a major prevention mechanism. Compared with 'regular' recessions, which affect men's employment more severely than women's employment, the employment drop related to social distancing measures has a large impact on sectors with high female employment shares. In addition, closure of schools and daycare centres has massively increased childcare needs, which has a particularly large impact on working mothers. The effects of the crisis on working mothers are likely to be persistent because of high returns to experience in the labour market.

It is observed that the state has undertaken various measures to assist the poor; however, some recommendations are suggested to further strengthen the support currently put in place:

- During the next phases of lockdown it is recommended that the COVID-19 grant compliance measures should be reduced to remove the requisite for banking details and proof of residence. This relaxation will allow those with valid identity and valid refugee and asylum seeking evidence to access the COVID-19 grant and thus assist poor women in increasing their monthly income.

- Noting that relief measures for access to water and sanitation have been provided to informal settlements, the state must endeavour to provide more sponsored masks and sanitiser to the most vulnerable and extend this offering to sponsored cleaning products such as bleach to assist poor women who have several burdens during COVID-19.

- Increasing free healthcare to the most vulnerable by taking healthcare to the people, this currently exists in the form of hospitals for those who have COVID-19; however, many poor women rely on free clinics to attain medication and treat themselves and their children. Going to such institutions during the pandemic increases their exposure. This burden could be lessened by availing of healthcare in communities to prevent rather than treat the pandemic. In South Africa, we have placed an enormous burden on community healthcare workers to address the gaps in our healthcare system when dealing with the human immunodeficiency virus and acquired immunodeficiency syndrome (HIV/AIDS) pandemic. These women are at the front line of performing care work without recognition and proper remuneration.

- Allowing for commerce in the informal sector such as vendors will also assist in providing much needed accessible food to poorer households. This can be done by maintaining social distancing as has been implemented in other parts of the world.

- Finally, stricter controls for aid being given to the poor, corruption is widely reported and therefore must be addressed so that relief aid actually reaches the people who are intended to receive this. There is further pressure on the livelihoods of poor households; these stricter controls also impact their ability to access food and basic necessities closer to home. The food aid therefore must reach poor communities as a matter of priority. 


\section{Acknowledgements Competing interests}

The author declares that she has no financial or personal relationships that may have inappropriately influenced her in writing this article.

\section{Author's contributions}

N.R. is the sole author of this research article.

\section{Ethical considerations}

This article followed all ethical standards for research without direct contact with human or animal subjects.

\section{Funding information}

This research received no specific grant from any funding agency in the public, commercial or not-for-profit sectors.

\section{Data availability}

Data sharing is not applicable to this article as no new data were created or analysed in this study.

\section{Disclaimer}

The views and opinions expressed in this article are those of the author and do not necessarily reflect the official policy or position of any affiliated agency of the author.

\section{References}

Alon, T., Doepke, M., Olmstead-Rumsey, J. \& Tertilt, M., 2020, The impact of COVID-19 on gender equality, viewed 19 June 2020, from https://www.nber.org/papers/w26947.

Altonji, J.G., Kahn, L.B. \& Speer, J.D., 2016, 'Cashier or consultant? Entry labor market conditions, field of study, and career success', Journal of Labor Economics 34(Supp 1), S361-S401. https://doi.org/10.1086/682938

Blouws, C., 2020, Covid-19: Womxn in South Africa more vulnerable than most viewed 19 June 2020, from https://www.dailymaverick.co.za/article/2020-03-24 covid-19-womxn-in-south-africa-more-vulnerable-than-most/.
Business Tech, 2020a, Ramaphosa announces 21 day coronavirus-locdkown, viewed 09 June 2020, from https://businesstech.co.za/news/ government/383927/ramaphosa-announces-21-day-coronavirus-lockdownfor-south-africa/.

Business Tech, 2020b, Social distancing in townships is a pipe dream, viewed 10 June 2020, from https://businesstech.co.za/news/lifestyle/395276/social-distancingin-townships-is-a-pipe-dream-report/.

Elsey, T., 2020, Unequal: The impact of the Covid-19 lockdown on the poor, viewed 10 June 2020, from https://www.dailymaverick.co.za/article/2020-04-09-unequalthe-impact-of-the-covid-19-lockdown-on-the-poor/\#gsc.tab $=0$.

Fourie, R., 2020, Covid-19 in SA: Food security challenges creating a gangster's paradise, viewed 18 June 2020, from https://www.iol.co.za/news/politics/ opinion/covid-19-in-sa-food-security-challenges-creating-a-gangstersparadise-47818884.

Jarosch, G., 2014, Searching for job security and the consequences of job loss, viewed 12 March 2021, from http://economics.mit.edu/files/10369.

May, C. \& Hamdulay, A., 2019, MayDay: The burden of unpaid care work on women viewed 20 June 2020, from https://www.iol.co.za/news/opinion/mayday-theburden-of-unpaid-care-work-on-women-22209106.

McLaggan, M., 2020, When the smoke clears: The ban on tobacco products in South Africa during COVID-19, viewed 08 February 2021, from https://globalinitiative.net/ analysis/tobacco-ban-covid-za/.

Overseas Development Institute, 2016, Report on women's work: Mothers children and the global care crisis, viewed 06 February 2021, from https:// bettercarenetwork.org/sites/default/files/Women $\%$ E2\%80\%99s $\% 20$ work- $\% 20$ Mothers $\% 2 \mathrm{C} \% 20$ children $\% 20$ and $\% 20$ the $\% 20$ global $\% 20$ childcare $\% 20$ crisis. pdf.

PLAAS, 2020, Homepage, viewed 18 June 2020, from https://www.plaas.org.za/.

Ramaphosa, C., 2020, Press statements, viewed from http://www.thepresidency.gov.za/ press-statements/statement-president-cyril-ramaphosa-measures-combat-covid19-epidemic.

Roncolato, L. \& Radchenko, N., 2016, 'Women's labor in South Africa - Time spent doing simultaneous paid and unpaid work', Electronic International Journal of Time Use Research 13(1), 58-90. https://doi.org/10.13085/ elJTUR.13.1.58-90

South African Government, 2020, Social grants - Corona virus- COVID-19, viewed 18 June 2020, from https://www.gov.za/coronavirus/socialgrants.

Statistics South Africa, 2015, Inequality trends report, viewed 20 June 2020, from http://www.statssa.gov.za/?p=12930.

Statistics South Africa, 2020, Quarterly labour force Survey Quarter 4: 2019, viewed 20 April 2020, from http://www.statssa.gov.za/?p=12948.

The Living Conditions Survey (LCS), 2014/2015, Media Release: Living Conditions Survey (LCS) 2014/2015, viewed 10 June 2020, from http://www.statssa.gov. $z a / ? p=9473$.

Tolmay, A. \& Morna, C., 2020, Safeguarding women's rights during the Covid-19 shutdown, viewed 20 June 2020, from https://mg.co.za/article/2020-03-24safeguarding-womens-rights-during-the-covid-19-shutdown/.

Visser, M. \& Ferrer, S., 2015, Farm workers' living and working conditions in South Africa: Key trends, emergent issues, and underlying and structural problems,
Report for the International Labour Organisation, viewed 05 February 2021, from Report for the International Labour Organisation, viewed 05 February 2021, from
https://www.ilo.org/wcmsp5/groups/public/---africa/documents/publication/ wcms_385959.pdf.

World Odometer, 2020, South Africa, viewed 11 June 2020, from https://www. worldometers.info/coronavirus/country/south-africa/. 